УДК 94+327 (496.5)

DOI: $10.26693 /$ ahpsxxi2020.02.102

\title{
ВИТОКИ ТА ІДЕЙНА ОСНОВА ПРОЕКТУ «ВЕЛИКА АЛБАНІЯ»
}

\author{
Людмила Вовчук, \\ e-mail: luda_vovchuk@ukr.net \\ ORCID: https://orcid.org/oooo-OOO2-8324-5235 \\ Чорноморський національний університет імені Петра Могили, \\ Украӥна, 540о3, м. Миколаїв, вул. 68 Десантників, 10 \\ Олександр Сирбу, \\ e-mail: sanyasyrbu@gmail.com \\ ORCID: https://orcid.org/oooo-ooo1-6300-4648 \\ Чорноморський національний університет імені Петра Могили, \\ Украӥна, 54оо3, м. Миколаїв, вул. 68 Десантників, 10
}

Зовнішньополітичний курс Республіки Албанія в кінці XX - на початку XXI cm., його основні тенденцї та пріоритети становлять одну з ключових проблем для розуміння того, що відбувається у даний час на Балкансъкому півострові $i$ в Європі в цілому. В регіоні немає іншої держави, в історї та сучасності якого були б так тісно переплетені державні й етнічні мотиви. Необхідно підкреслити, що саме албанський фактор відіграє на даний час одну з ключових ролей у визначенні архітектури безпеки у балканському регіоні й ия роль, у перспективі, буде тільки зростати в силу його особливостей і тієї підтримки, якою він користується ззовні.

Ключові слова: Албанія, проект (ідея) «Велика Албанія», етнічні проблеми, Балкани

Постановка проблеми. Проект «Велика Албанія» є ідеєю албанців зі створення держави, де албанський етнос $\epsilon$ переважаючим. Цей проект підтримується державною владою, яка відкрито наголошує на необхідності об'єднання територій, де мешкає більшість албанського населення. Як відомо, Албанія виділяється з-поміж інших балканських держав саме за релігійно-конфесійною складовою, тобто більшість албанського населення (56,7\% - мусульмани, 10,03\% - католики, 6,75\% - православні, 2,09\% - бекташи, о,14\% - євангелісти, 5,49\% - некваліфіковані віруючі та 2,5\% - атеїсти ${ }^{1}$ сповідує іслам, тому має серйозну підтримку всього ісламського світу.

Аналіз попередніх досліджень. Витоки та ідейна основа проекту «Велика Албанія» стали предметом аналізу українських, російських, балканських і західних науковців. Серед українських вчених варто виокремити роботу О. Ворони르, який у своїй праці підкреслює, що «Сьогодні чи не найбільшою загрозою миру на Балканах є албанський іредентизм - рух за об'єднання населених албанцями земель у межах єдиної держави. Принаймні саме в цьому головну проблему вбачають офіційні сербська та російська пропаганди»3.Значну увагу даній тематиці приділяють російські автори:

\footnotetext{
${ }^{1}$ Instituti i Statistikave. Albania (2011). Njoftim per Media. Fjala e Drejtorit të Përgjithshëm të INSTAT, Ines Nurja gjatë prezantimit të rezultateve kryesore të Censusit të Popullsisë dhe Banesave 2011. $3 . \quad$ Retrieved from: https://web.archive.org/web/20170326091156/http://www.instat.gov.al/media/177358/njoftim_pe r_media_-_fjala_e_drejtorit_te_instat_ines_nurja_per_rezultatet_finale_te_census_2011.pdf ${ }^{2}$ Ворона, О. (2020, 30 червня). Проєкт «Великої Албанї̈» - мрї̈ націоналістів чи цілеспрямована державна політика? / Аналітичний центр ADASTRA. Retrieved from: https://adastra.org.ua/blog/proyekt-velikoyi-albaniyi-mriyi-nacionalistiv-chi-cilespryamovanaderzhavna-politika

3 Ibidem.
} 
Е. Гуськова4, Н. Туров5, П. Іскандеров 6 та ін. Не менш важливими $є$ праці балканських вчених, таких, як Г. Арш7, Х. Трнавиц8.

Головна мета цієї статті полягає у дослідженні витоків та ідейної основи проекту «Велика Албанія».

Виклад основного матеріалу. На думку українського дослідника О. Ворони витоки ідеї створення «Великої Албанії» тяжіють до XV ст., коли більша частина Балканського півострова опинилася у складі Османської імперії. Під час турецького панування велика кількість албанців прийняла іслам, що зумовило їхнє перебування у порівняно привілейованому становищі в складі мусульманської держави. Відповідно території, на яких вони проживали, поступово розширювалися.

Початок націоналістичних прагнень албанців ознаменував Сан-Стефанський мирний договір і Берлінський конгрес 1878 р., за якими незалежність здобули більшість сусідів Албанії, окрім самої країни, яка, окрім того, втратила значні території. Не бажаючи миритися з цим, албанці організували спротив у рамках так званої Призренської ліги. Однак тоді ця ідея не увінчалася успіхом, оскільки у 1880 р. Призренська Ліга албанського народу була розігнана. Але саме тоді був вперше сформульований проект щодо створення «Великої Албанії»9, до складу якої мали увійти чотири албанських вілайєта на території Османської імперії: Манастир, Яніна, Шкодер і Косово. Наразі ці території розпорошені наступним чином:

- в Сербії: територія Косово і Метохії, долина річки Південна Морава на сході, від округу Топліца до нішаського округу на північному сході, велика частина Рашської області на північному заході;

- в Чорногорії: майже вся східна частина Чорногорії до м. Подгоріца;

- $\quad$ в Македонії: ціла територія на захід від р. Вардар, території на північ і на північний схід від м. Скоп'є;

- в Греції: північно-західна частина Греції (грецька частина Епіру), територія до Амбракійскої затоки ${ }^{10}$.

Реалізація проекту «Велика Албанія» на практиці відбулася під час італійськонімецької окупації 1939-1944 pp.

7 квітня 1939 р. фашистська Італія Беніто Муссоліні захопила «Країну чорних орлів», перетворивши ії на свій протекторат. Італійці вирішили зробити ставку на албанський іредентизм і використати його задля втілення власної мети щодо захоплення Балкан. До протекторату було приєднано Косово разом із півднем Сербії, прикордонні регіони Чорногорії, Західну Македонію. Єдиною територією, на яку претендувала Албанія, але яка залишилася за їі межами, став грецький Епір або Чамерія, як її називали албанці. Ці землі Італія взяла під свій безпосередній контроль. Німці, замінивши італійців у 1943 р., албанські кордони не чіпали, проте після завершення Другої світової війни союзники повернули Албанії кордони 1913 року ${ }^{11}$.

Враховуючи, що німецькі й італійські війська сприймалися албанцями як визволителі, то вони сподівалися, що вони нададуть їм допомогу в створенні єдиної національної албанської держави. Дійсно, при них було створено Велике Герцогство Албанія (крім Албанії туди входили території Метохії, центрального Косово і західної Македонії). Однак, після виходу Італії з війни територія Великого герцогства перейшла до складу фашистської Німеччини. У результаті була сформована Друга Призренська

\footnotetext{
4 Гуськова, Е.Ю. (2006). Албанский фактор кризиса в бывшей Югославии. Политика двойных стандартов международных организаций. Аналитические записки, 18, 67-90.

5 Туров, Н.Л. (2014). Идеологический проект «Великая Албания» на современной политической карте мира. Сравнительная політика, 4, 39-44.

${ }^{6}$ Искендеров, П.А. (2012). «Великая Албания»: теория и практика. Вопросы истории, 1, 31-46.

7 Арш, Г.Л. (1992). Краткая история Албании. Москва: Наука.

8 Трнавиц, Х. (1987). Моја исповест о Косову. Београд.

9 Арш, Г.Л. (1992). Краткая история Албании. Москва: Наука.

10 Ворона, О. (2020, 30 червня).

${ }^{11}$ Ibidem.
} 
Ліга, в якій брали участь албанські націоналісти. Керівництво цієї Ліги відкрито наголошувало про необхідність переселення сербів з території Великого Герцогства. Однак, цей проект не увінчався успіхом. Цікавим $\epsilon$ те, що даний проект не втратив своєї актуальності й сьогодні, оскільки албанці намагаються відтворити німецькоіталійську ідею 1939-1944 pp..$^{12}$

Чотири роки фашистської окупації стали фактично єдиним періодом існування «Великої Албанії». Подібна ситуація зберігалася аж до звільнення вищевказаних територій спочатку від італійської, а потім і від німецької окупації. Держави антигітлерівської коаліції в рамках післявоєнного врегулювання прийняли рішення повернути Албанію до її колишніх кордонів, які, в цілому, відповідали рішенням Лондонської наради послів великих держав 1912-1913 рр.

В одному зі звернень Генерального Штабу національно-визвольної армії Албанії до Йосипа Броз Тіто говорилося буквально наступне: «Ми не залишалися без вашої допомоги, про яку наш народ знає і за яку вдячний. Братство по зброї наших народів було скріплене спільною боротьбою, і пролита кров зцементувала цю дружбу, яку ніщо не може зруйнувати»13.

Однак у ході обговорення принципів розмежування Албанії та Югославії вектор дискусій постійно змінювався. У грудні 1943 р. на зустрічі представників комуністичних партій Албанії та Югославії було прийнято рішення, згідно з яким єдиним шляхом здобуття свободи було надання всім народам, включаючи албанців, можливості прийняти рішення про свою власну долю, у тому числі й право на самовизначення, аж до відокремлення. Однак вже в 1945 р. на конференції у Призрені це рішення було переглянуто, і представники комуністів Косово підтримали входження даної області до складу Сербії, а не Албанії ${ }^{14}$.

Як зазначає Е. Гуськова, за час війни територію Косова, за різними даними, покинули від 100 до 200 тис. сербів і чорногорців, а населили багато тисяч албанців з Албанії, які так і залишилися у цих краях, використовуючи сприятливу політичну обстановку в Югославії у 1944-1948 pр. Численні маніфестації албанського населення Косова, що проходили у 1945 р., висловлювали небажання перебувати у складі Сербії. Тіто намагався заспокоїти ситуацію, з одного боку, заявою про передбачуване входження Косова до складу Албанії, а з іншого, - звільненням албанців від відповідальності за злочини проти сербського населення, вчинені під час війни 15. При цьому албанці отримали у своє розпорядження землі сербів і чорногорців, які не мали можливості повернутися в Косово, у тому числі і в силу заборони, введеної на державному рівні ${ }^{16}$.

Албанізація слов'янських земель відбувалася під чітким керівництвом Компартії Югославії й особисто Б. Тіто. 6 березня 1945 р. було прийнято постанову «Про тимчасову заборону повернення колоністів в місця їх колишнього проживання», тобто до Македонії, Косова, Метохії, Срем і Воєводіни. Площа земель сербів і чорногорців, які не повернулись, становила, за деякими відомостями, близько 25 тис. га - все це було віддано албанцям. Крім того, після 1948 р. в край було переселено чимало біженців 3 Албанї̈17.

По суті, Броз Тіто більше був зацікавлений створенням сильної балканської держави - Югославії. Тому, без докорів сумління, він готовий був пожертвувати Косово, аби зацікавити Албанію. Надалі обговорення проблеми Косово та державного устрою самої Албанії у перші повоєнні роки проходило в рамках здійснення ідеї створення

12 Туров, Н.Л. (2014), 39.

13 Арш, Г.Л.(1992), 382.

14 Perolli, G. (2002). Konferenca e Bujanit. New York, 48.

15 Гуськова, Е.Ю. (2006), 70.

${ }^{16}$ Поповић, Н.Б. (Еd.) (2001). Косово и Метохија у великоалбанским плановима: 1878-20оо. Београд: Институт савремене историје, 141.

17 Пономарева, Е.Г. (2018). Албанский фактор дестабилизации Западных Балкан: сценарный подход. Вестник МГИМО-Университета, 2 (59), 104. 
Балканської федерації. Першим кроком на цьому шляху, на думку Сталіна і Тіто, повинно було стати об’єднання Албанії з Югославією.

У березні-квітні 1947 р. в Белграді проходили складні переговори щодо укладення двосторонньої торговельної угоди на основі пропозицій югославської сторони. Документ передбачав відмову Албанії від монополії на зовнішню торгівлю, оскільки всі експортно-імпортні операції повинні були здійснюватися винятково югославськими організаціями ${ }^{18}$.

Упродовж 1947 р. Тирана і Белград досягли домовленостей про парифікацію (прирівнювання) монетної системи, яка передбачала прирівнювання албанського лека до югославського динара, а також про уніфікацію цін, митний союз, обов'язковості погодження народногосподарських планів і створенні спільних товариств. Ця лінія в цілому відповідала резолюції V Пленуму ЦК Комуністичної партії Албанії 1946 р., в якій, зокрема, говорилося: «Наша албанська політика повинна орієнтуватися на більш тісний і конкретний зв'язок з Югославією». Однак це зустріло заперечення з боку тієї частини албанського керівництва, яке вбачало у форсованому поглибленні господарської інтеграції з Югославією загрозу національному суверенітету Албанії. При цьому посилалися на висловлювання Й. Сталіна, який у ході зустрічі з албанської урядовою делегацією на чолі з А. Ходжа, що відбулася в Москві у липні 1947 р., заявив, що Албанія повинна встати на свої власні ноги ${ }^{19}$.

Наприкінці 1947 р. Албанія та Югославія приступили до обговорення заходів щодо об’єднання армій двох країн. Спочатку передбачалася передислокація 2-ї пролетарської стрілецької дивізії югославської армії в один з потенційно конфліктних районів - місто Корча недалеко від албансько-грецького кордону. Однак радянськоюгославський конфлікт, який досяг своєї кульмінації у середині 1948 р., поховав плани створення югославсько-албанської федерації. У рамках резолюції Інформбюро «Про становище в Компартії Югославії» від 28 червня 1948 р., албанський уряд вже 1 липня оголосив про анулювання всіх двосторонніх договорів і про висилку з країни югославських радників, число яких, за деякими даними, наближалося до 600 осіб ${ }^{20}$.

Подібний розвиток подій, а також посилення протидії західних держав, які побоювалися появи на Балканах «малого СРСР», звело нанівець всі зусилля по створенню Балканської федерації як в їі максимально розширених кордонах, включаючи Албанію, Югославію, Болгарію, Румунію та Грецію, так і у вигляді потрійного об'єднання Белграда, Тірани та Софії, або хоча б у формі албансько-югославських наддержавних структур.

Різке зростання мусульманського населення у Македонії було визначене масовою міграцією мусульман з Косово, Санджака, Боснії і Герцеговини. Тільки 31951 по 1956 pр. до Македонії з цих районів переселилося близько 20 тис., а також більше 50 тис. мігрантів з Албанії, яким, у дусі гасла «братерства і єдності» югославське керівництво надало громадянство СФРЮ21.

Необхідно відзначити, що албанський елемент у Македонії, будучи найчисленнішим і найбільш організованим, послужив основою для релігійної та етнічної ідентифікації решти мусульманського населення республіки. Відбулася албанізація ісламської релігійної громади Македонії, а албанська мова у соціалістичний період витіснила всі інші мови в ісламських теологічних училищах і мечетях.

Що ж стосується соціально-економічних і політичних преференцій, то Конституція СФРЮ 1974 р. надала Косово і Метохії найширші за всю історію цієї території політичні права: автономія стала повноправним суб'єктом федерації. При цьому економічний тягар утримання краю залишився за федерацією. Косово постійно дотувалося з Фонду федерації, мало пільги при розподілі республіканських валютних кош-

\footnotetext{
${ }^{18}$ Арш, Г.Л. (1992), 404.

19 Ibid, 405 .

${ }^{20}$ Ibid, 406.

${ }^{21}$ Пономарева, Е.Г. (2018), 107-108.
} 
тів і кредитів МБРР, користувалося асигнуваннями з бюджету федерації для фінансування освіти та охорони здоров'я.

Протягом всього соціалістичного періоду процес зростання албанського націоналізму не припинявся, а автономний край Косово і Метохія залишалися центром сепаратизму. Проте, не дивлячись на це, офіційно «проблеми Косово» і ширше - албанського питання в Югославії не існувало. Саме у соціалістичній Югославії албанський сепаратизм та ірредентизм остаточно сформувався у завершену інституційну й ідеологічно обгрунтовану систему².

Майже відразу після розгрому осередків «Балі Комбетар» у краї була створена мережа підпільних груп, члени яких займалися пропагандою албанізму, налагоджували зв’язки з керівництвом країни. I вже до кінця 1950-х - початку 1960-х рр. нелегальний рух за об'єднання «етнічних албанських земель» прийняв організовану форму. У 1961 р А. Демачи заснував «Революційний рух за об’єднання албанців», пізніше він став називатися «Національний рух за звільнення Косова й інших албанських земель». У Статуті руху було записано: «Основна і кінцева мета руху - звільнення шіптарських (албанських) країв, анексованих Югославією, та їх об'єднання з матір'ю Албанією»23. Щоб досягти поставлених цілей, передбачалося «вжити всіх засобів»політичні, пропагандистські, збройну боротьбу, а також всенародне повстання.

У другій половині XX ст. великоалбанська ідея включала претензії Албанії на Косово, значну частину якого складали албанці-мусульмани. 3 урахуванням того, що зараз чимало албанців проживають не тільки у Косово, але й у Македонії, ідея «Великої Албанії» залишається актуальною. Нинішня влада відкрито не заявляє такі вимоги, хоча радикальні партії не відмовилися від цієї ідеї24.

В кінці 1960-х рр. у Косово і Метохії було дозволено використання албанських національних символів (національних символів Албанії), були створені умови для максимально наукового та культурного співробітництва з Тіраною. Ці здобутки додали сили націоналістам ${ }^{25}$.

У період правління Енвера Ходжі, особливо в останні роки його життя, претензії Албанії на Косово й у цілому їі великоалбанські настрої, якщо відкрито і не афішувалися, то принаймні широко поширювалися серед косовського населення, особливо серед студентів Університету в Пріштині ${ }^{26}$.

Розпад на початку 1990-х рр. єдиної Югославії запустив проблему «Великої Албанії» у дію. Різні геополітичні концепції перебудови Балкан і всієї Центральної та Східної Європи, які з'явилися на той час, сприяли зростанню національної самосвідомості народів великого регіону, зміцнювали відцентрові тенденції та ставили національні рухи на шлях сепаратизму. Зворотним боком цього процесу стало поширення ідеї «великої держави» у різних Балканських країнах. Прихильники такої ідеї спиралися на традиційні концепції, які у великій кількості стали з'являтися разом з утворенням нових національних держав безпосередньо на Балканах.

У післявоєнний час світ заговорив про «Велику Албанію» лише з моменту виникнення косовського конфлікту та проголошення незалежності Косово у 2008 р. (південного регіону Сербії, населеного переважно етнічними албанцями) 27.

До ключових документів «Великої Албанії» варто віднести «Меморандум» Форуму албанських інтелектуалів Косово від 26 жовтня 1996 р. і «Платформу рішення албанського національного питання» Албанської академії наук, складену влітку

22 Ibid, 106.

23 Ануфриева, И.В., Гуськова, Е.Ю. (2006). Албанский фактор в развитии кризиса на территории бывщей Югославии. Документы. Т. I (1878-1997 гг.). Москва: Индрик, 24.

24 Горло, Н.В. (2019). Функціональні та концептуальні моделі політики іредентизму: дис.... д-ра політ. наук: 23.00.02; Львів. нац. ун-т ім. Івана Франка. Львів, 174.

25 Popović, N.B. (2001), 169.

26 Трнавиц, Х. (1987), 101.

27 Ворона, О. (2020, 30 червня). 
1998 р. ${ }^{28}$ Ці документи були перекладені англійською мовою та поширені по всьому світу.

Документ (стаття) «Платформа для вирішення албанського національного питання» (жовтень 1998 р.) було прийнято Албанською академією наук після багатьох внутрішніх дискусій. Цей документ за своїм змістом, повідомленнями та рекомендаціями, безумовно відображає політику країни і вносить пропозиції щодо подальших подій у регіоні, але й містить пояснення албанських внутрішньополітичних установок.

Відповідно до цього документу, албанці зазнали найбільшої територіальної роздробленості серед народів Європи. Сьогодні їх територія розділена між п'ятьма країнами на півострові, з яких лише половина знаходиться в межах національної держави албанців. Документ підкреслює, що поза межами Албанії більшість етнічних албанських територій перебувають під сербською окупацією29.

Документ (стаття) «Платформа для вирішення албанського національного питання» демонструє, що серед етнічних албанських територій, що перебувають під сербською владою, знаходиться і провінція Косово, де албанці становлять близько 90\% від загальної чисельності населення.

Також до албанських територій цей документ відносить області, розташовані у Македонії, Чорногорії та Греції. I «ця територіальна роздробленість постійно є джерелом турботи про всю албанську націю, всередині та за межами Албанії»30. Цим документом дії Сербії по відношенню до Косова є терором.

Подавши «Платформу», Албанська академія наук мала намір організувати Національні збори, в яких інтелігенція з усіх етнічних районів і спільнот діаспори зможе брати участь і підтримає цей документ. Творці цього документу відзначали, що албанське національне питання, у контексті руху за звільнення албанської території від іноземної окупації та її об’єднання в єдину національну державу, народилося одночасно з національних рухів інших народів на Балканському півострові 31 .

Відповідно до концепції «Великої Албанії», викладеної у «Меморандумі» Форуму албанських інтелектуалів Косово від 26 жовтня 1996 р. і «Платформі рішення албанського національного питання», боротьба за реалізацію ідеї буде вестися у такий спосіб:

1. Косово з південними землями Сербії (муніципалітети Прешево, Буяновец і Медведжа) повинні стати незалежною державою з гарантіями рівної відкритості як Сербії, так і Албанії. Мінімум, на що албанці згодні, - статус третього державного утворення у співдружності Сербії і Чорногорії.

2. Проблема албанців на території Македонії, які складають 35\% населення країни, може бути вирішена двома способами: або Македонія стає двонаціональною державою, або у складі Македонії буде утворена автономна албанська національна область.

3. Території Чорногорії, де превалюють албанці, повинні стати автономною областю зі столицею в Ульцині.

4. У Греції повинні розширити права албанців шляхом дозволу викладання їм у початкових школах албанської мови та ввести предмети «Історія Албанї», «Історія албанської літератури» та ін. албанською мовою. Згодом виділення в автономну область муніципалітету Чамера ${ }^{2}$.

На другому етапі ці держави повинні об’єднатися з Албанією в єдину державу. Причому найважливішу роль у створенні «Великої Албанії» має відіграти незалежне

28 Филимонова, А. (2021, 30 января). «Великая Албания»: капкан для Сербии и России. Retrieved from https://regnum.ru/news/polit/3175007.html

29 Mirchev, D. (2015). The Balkan Mega-ethnos National Doctrines of Macedonia's neighbors. Toronto, Canada: Risto Stefov. Retrieved from: http://www.pollitecon.com/html/ebooks/ristostefov/The-Balkan-Mega-ethnos.pdf

$3^{30}$ Ibidem.

${ }^{31}$ Ibidem.

32 Искендеров, П.А. (2012), 39. 
Косово, яке повинно зіграти передовика у створенні національного албанського державного утворенняз3.

Важливою відмінною рисою проекту «Великої Албанії», у порівнянні з аналогічними концепціями в рамках сербського, болгарського, грецького чи хорватського національних рухів, є відсутність єдиного «столичного центру», який збирав би навколо себе відповідні етнічні землі, де історично були Белград, Софія, Афіни та Загреб. Це було пов’язано, насамперед, з великою розкиданістю земель, населених албанцями, в основному серед чотирьох вілайєтів Османської імперії - Скутарійского, Янінского, Бітольського та Косовського. Така адміністративно-територіальна система існувала у кінці XIX ст., тобто в момент становлення албанського національного руху. Слід також враховувати, що столиця нинішньої Албанії - місто Тирана, спочатку не було ні політичним, ні економічним, ні культурним центром країни на відміну від Шкодера, Дурреса, Вльори або нині косовської Призрени. Крім того, історична свідомість албанців не містить у собі пам'яті про «албанську імперію», що не існувала у період раннього середньовіччя на відміну від сербських держав або болгарських царств.

У 1992 р. албанські радикали зібралися у македонському місті Струга для того, щоб проголосити створення так званої «Республіки Ілліріда» і зажадати федералізації Македонії. 3 початку 1990-х років радикальні лідери македонських албанців продовжували відкрито закликати до перетворення своєї країни у слов'янсько-албанську конфедерацію «Республіка Македонія - Ілліріда». При цьому вони загрожували тим, що самовизначення буде розвиватися за косовським зразком. Це незважаючи на те, що офіційною позицією албанських партій правлячої коаліції залишалося збереження тогочасного державного устрою країниз4.

Протягом 1990-х рр. два ключові чинники сприяли радикалізації вимог, висунутих албанцями: поглиблення сербсько-албанських протиріч у Косово й ігнорування міжнародним співтовариством вирішення косовської проблеми на відміну від врегулювання ситуації у Словенії, Хорватії, Боснії і Герцеговині та навіть Македонії. Така політика призвела до того, що упродовж 1997-1998 pр. у Косово, замість дотримування ненасильницького курсу «Демократичної ліги Косово» на чолі з Ібрагімом Ругова, провідну роль стала грати воєнізована «Армія звільнення Косова»(АОК).

У липні 1998 р. прес-секретар АОК (і майбутній голова Асамблеї Косово) Якуп Краснічі публічно заявив, що метою даного формування є об'єднання всіх албанонаселених земель 35 . Аналогічним було і новорічне звернення Генерального Штабу АОК, озвучене напередодні 1998 р. У ньому містився заклик зробити 1998-1999 рр. роками об'єднання албанців, свободи та незалежності для Косово ${ }^{36}$.

Антиурядові бойові дії албанських збройних загонів, що розгорнулися у 19992001 pр. у Прешевській долині та Македонії, тісно пов’язаних з АОК, стали наступним кроком реалізації великоалбанского сценарію. Відсутність підтримки з боку НАТО та Європейського Союзу змусило сепаратистів піти на домовленості про мир 3 Белградом і Скоп'є. Однак одностороннє проголошення у лютому 2008 р. незалежності Косово та його визнання провідними західними державами додало ідеологам «Великої Албанії» новий імпульс. У самій Албанії за об’єднання Косово та Албанії відверто висловлювався ще у 2001 р. голова Демократичного альянсу Арбен Імамі 37.

Прем’єр-міністр Албанії (2005-2013) та лідер Демократичної партії Албанії Салі Беріша виступав за створення єдиного албанського культурно-національного простору, але при цьому утримувався від прямих закликів до перекроювання балканських кордонів. Багато у чому це пов'язано з впливом лідерів Європейського Союзу, куди

\footnotetext{
33 Туров, Н.Л. (2014), 40.

34 Искендеров, П.А. (2012), 40.

35 Филимонова, А. (2021, 30 января).

${ }^{36}$ Ibidem.

37 Ibidem.
} 
Тирана має намір вступити якомога швидше. Як зазначав глава МЗС Албанії наприкінці 1990-х років Паскаля Мильо: «мета всіх албанців полягає у створенні албанської зони, що включає в себе все албанське населення Південно-Східної Європи, інтегрованої в євроатлантичні структури» 38 .

Ще у 1992 р., відразу після приходу до влади, С. Беріша заявив в одному 3 інтерв’ю, що «ідеї створення Великої Албанії абсолютно невластиві албанським правлячим колам і політичним силам». Така констатація відразу викликала різку відповідь з боку одного з провідних албанських інтелектуалів, академіка Реджепа Чосья, який вказав у відкритому листі газеті «Іллірія», що видається у США, що Албанія ніколи не визнавала її існуючі кордони і завжди намагалася нагадати міжнародним колам, що ці заходи є несправедливими, які поділяють албанські землі на дві частини. Це кордони, які проходять по самому серцю албанського народуз9.

Висновки. Ідея «Великої Албанії» має глибоке історичне коріння. Однак, не є офіційною концепцією зовнішньої політики албанського уряду. «Велика Албанія» 6 ідеєю возз'єднання всіх територій, на яких проживає албанський етнос. У цьому випадку албанці будуть претендувати на частину території Греції, половину Македонії, все Косово, частину територій південної Сербії, а також на половину Чорногорії. На сьогоднішній день реалізація такого масштабного територіального перерозподілу на Балканах практично неможлива.

\section{REFERENCES}

Anufriyeva, I.V., \& Guskova, E.Yu. (2006). Albanskiy faktor $v$ razvitii krizisa na territorii byvshey Yugoslavii [Albanian factor in the development of the crisis in the territory of the former Yugoslavia]. Dokumenty. T I (1878-1997 gg.). Moskva: Indrik [in Russian].

Arsh, G.L. (1992). Kratkaya istoriya Albanii [A brief history of Albania]. Moskva: Nauka [in Russian].

Filimonova, A. (2021, 30 yanvarya). «Velikaya Albaniya»: kapkan dlya Serbii i Rossii [«Great Albania»: a trap for Serbia and Russia]. Retrieved from https://regnum.ru/news/polit/3175007.html [in Russian].

Guskova, E.Yu. (2006). Albanskiy faktor krizisa v byvshey Yugoslavii. Politika dvoynykh standartov mezhdunarodnykh organizatsiy [Albanian factor in the crisis in the former Yugoslavia. The policy of double standards of international organizations]. Analiticheskiye zapiski, 18, 67-90 [in Russian].

Horlo, N.V. (2019). Funktsionalni ta kontseptualni modeli polityky iredentyzmu [Functional and conceptual models of irredentism policy]. (Doctor's thesis). Lviv [in Ukrainian].

Iskenderov, P.A. (2012). «Velikaya Albaniya»: teoriya i praktika [«Great Albania»: theory and practice]. Voprosy istorii, 1, 31-46 [in Russian].

Mirchev, D. (2015). The Balkan Mega-ethnos National Doctrines of Macedonia's neighbors. Toronto, Canada: Risto Stefov. Retrieved from: http://www.pollitecon.com/html/ebooks/ristostefov/The-Balkan-Mega-ethnos.pdf [in English].

Perolli, G. (2002). Konferenca e Bujanit. New York: Libri [in Albanian].

Ponomareva, E.G. (2018). Albanskiy faktor destabilizatsii Zapadnykh Balkan: stsenarnyy podkhod [Albanian factor of destabilization of the Western Balkans: scenario approach]. Vesnik MGIMO Universiteta, 2 (59), 99-124 [in Russian].

Popović, N.B. (Ed.) (2001). Kosovo i Metohija u velikoalbanskim planovima: 1878-20oo. Belgrade [in Albanian].

Trnavits, Kh. (1987). Moia ispovest o Kosovu [My confession about Kosovo]. Bilgrade [in Albanian].

Turov, N.L. (2014). Ideologicheskiy proyekt «Velikaya Albaniya» na sovremennoy politicheskoy karte mira [Ideological project «Great Albania» on the modern political map of the world.]. Sravnitelnaya politika, 4, 39-44 [in Russian].

Uzun, Yu. (2015). Project «Greater Albania» and processes of its practical realization. European Political and Law discourse, 2, 166-174 [in English].

Vorona, O. (2020, 30 chervnia). Proiekt «Velykoi Albanii» - mrii natsionalistiv chy

${ }^{38}$ Uzun, Yu. (2015). Project «Greater Albania» and processes of its practical realization. European Political and Law discourse, 2, 171.

39 Искендеров, П.А. (2012), 44. 
tsilespriamovana derzhavna polityka? [Greater Albania project - dreams of nationalists or purposeful state policy?]. Retrieved from https://adastra.org.ua/blog/proyekt-velikoyi-albaniyimriyi-nacionalistiv-chi-cilespryamovana-derzhavna-politika [in Ukrainian].

Liudmyla Vovchuk, Petro Mohyla Black Sea National University, Mykolaiv, Ukraine

ORCID: https://orcid.org/oooo-ooo2-8324-5235

Oleksandr Syrbu, Petro Mohyla Black Sea National University, Mykolaiv, Ukraine ORCID: https://orcid.org/oooo-ooo1-6300-4648

\section{The foundation of the «Greater Albania» project}

The Greater Albania project is the idea of Albanians to create a state where the Albanian ethnic group is predominant. This project is supported by the state authorities, who openly declare the need to annex territories with a predominant Albanian population. Albania stands out from its neighbors on religious grounds, so it has enlisted the support of the entire Islamic world.

The foreign policy course of the Republic of Albania at the end of the $X X$ - beginning of the XXI century, its main tendencies and priorities are one of the key problems for understanding what is happening now on the Balkan Peninsula and in Europe as a whole. There is no other state in the region whose history and modernity are so closely intertwined with state and ethnic motives. The topic of the study is part of a wider range of issues related to international relations in the Balkans and in the region of SouthEastern Europe as a whole. It should be emphasized that the Albanian factor currently plays one of the key roles in determining the security architecture in the Balkan region and this role, in the long run, will only increase due to its features and the support it enjoys from outside.

The origins and ideological basis of the Greater Albania project are clarified in the paper. Greater Albania today has little chance of becoming a reality. Instead, Russia's efforts to increase its influence over Europe's «powder keg» under the guise of «good intentions», in particular, to protect the fraternal Balkan peoples from Albanian nationalism, are more real.

Keywords: Albania, project (idea) «Greater Albania», ethnic problems, Balkans 